\title{
TUGAS POKOK DAN FUNGSI APOTEKER SEBAGAI PELAKSANA PENGADAAN PERBEKALAN FARMASI DI RUMAH SAKIT
}

\author{
Ni Made Widi Astuti ${ }^{1 *}$, Kristina M.L. ${ }^{1}$, R. Ayu Indah K.M. ${ }^{1}$, Ni Putu Yesi A.D. ${ }^{1}$, Ni \\ Luh Gede Wiwin P. ${ }^{1}$, \\ ${ }^{1}$ Program Studi Profesi Apoteker, Fakultas Matematika dan Ilmu Pengetahuan Alam \\ Universitas Udayana \\ *E-mail: ni_made_widi_astuti@unud.ac.id
}

\begin{abstract}
ABSTRAK
Salah satu pelayanan kefarmasian di Instalasi Farmasi Rumah Sakit adalah pengelolaan perbekalan farmasi. Pada tahap pengelolaan, pengadaan perbekalan farmasi sangat berpengaruh pada ketersediaan obat di rumah sakit. Pengadaan merupakan kegiatan untuk merealisasikan perencanaan kebutuhan perbekalan farmasi. Proses pengadaan perbekalan farmasi harus menjamin ketersediaan, jumlah, waktu yang tepat dengan harga yang terjangkau sesuai standar mutu. Seorang apoteker bertanggung jawab dari setiap kegiatan pengadaan perbekalan farmasi di rumah sakit. Oleh sebab itu diperlukan pemahaman bagi apoteker terkait tugas pokok dan fungsi apoteker dalam sistem pengadaan. Studi ini bertujuan untuk membahas mengenai tugas pokok dan fungsi apoteker dalam pengelolaan obat, khususnya pengadaan perbekalan farmasi di rumah sakit. Metode penelitian yang digunakan adalah studi pustaka terkait pengadaan perbekalan farmasi di rumah sakit. Tugas pokok dan fungsi apoteker dalam proses pengadaan perbekalan farmasi meliputi pemilihan perbekalan farmasi yang dibutuhkan, menentukan pemasok, menentukan metode pengadaan hingga melakukan evaluasi terhadap proses pengadaan di rumah sakit.
\end{abstract}

Kata kunci: tupoksi apoteker, rumah sakit, pengelolaan perbekalan farmasi, pengadaan perbekalan farmasi, instalasi farmasi

\begin{abstract}
One of the pharmaceutical services in the Hospital Pharmacy Installation is the management of pharmaceutical supplies. At the management stage, the procurement of pharmaceutical supplies greatly affects the availability of drugs in hospitals. Procurement is an activity to realize the planning needs for pharmaceutical supplies. The process of procuring pharmaceutical supplies must ensure availability, quantity, correct time at affordable prices according to quality standards. A pharmacist is in charge of every pharmaceutical supplies activity in the hospital. Therefore an understanding is needed for pharmacists regarding the main duties and functions of pharmacists in the procurement system. This study aims to discuss the main duties and functions of pharmacists in drug management, particularly the procurement of pharmaceutical supplies in hospitals. The research method used is literature study related to the procurement of pharmaceutical supplies in hospitals. The main duties and functions of pharmacists in the pharmaceutical supplies process include selecting the required pharmaceutical supplies, determining suppliers, determining the procurement method to evaluating the procurement process in hospitals.

Keywords: the main duties and functions of pharmacists, hospital, management of pharmaceutical supplies, procurement of pharmaceutical supplies, Pharmacy installation

\section{PENDAHULUAN}

Saat ini rumah sakit berkembang menjadi sangat pesat, termasuk di Indonesia. Hal ini berhubungan

dengan pengelolaan obat, salah satunya pada tahap pengadaan obat, yang saat ini menuntut rumah sakit
\end{abstract}


untuk dapat melakukan pelayanan dengan baik. Rumah sakit harus mampu meningkatkan kualitas dan efektivitas pelayanan kefarmasian di rumah sakit. Sehingga dapat mencapai dan menjamin kebutuhan konsumen ataupun pasien.

Pelayanan kefarmasian di rumah sakit merupakan hal yang tidak dapat dipisahkan dari tatanan pelayanan kesehatan di rumah sakit yang berorientasi kepada pelayanan pasien, persediaan (pengadaan) perbekalan farmasi, alat kesehatan, dan bahan medis habis pakai. Setiap instalasi farmasi di rumah sakit memiliki peranan yang penting salah satunya adalah pengelolaan perbekalan farmasi mulai dari perancangan kebutuhan obat, penyediaan, penyimpanan, penyiapan, peracikan, serta pelayanan langsung kepada pasien dan pengendalian semua persediaan kesehatan yang beredar dan yang akan dipergunakan di suatu rumah sakit [1].

Pengadaan perbekalan farmasi dirumah sakit adalah kegiatan merealisasikan perencanaan kebutuhan perbekalan farmasi di rumah sakit, seperti pemilihan, penentuan jumlah yang dibutuhkan, menentukan metode penyediaan, menentukan distributor obat, mengawasi tahapan pengadaan obat hingga melakukan pembayaran. Pengadaan perbekalan farmasi dapat dikatakan efektif, apabila telah mampu memenuhi ketersediaan, jumlah, dan waktu yang tepat dengan meminimalkan biaya dan telah sesuai dengan standar mutu yang ditetapkan [2].
Persediaan obat yang terlalu banyak maupun terlalu sedikit dapat menyebabkan rumah sakit mengalami kerugian. Untuk meminimalkan kerugian yang terjadi maka seorang apoteker di Rumah Sakit harus menyesuaikan kebutuhan dan biaya pengadaan yang tersedia.

Kerugian dalam proses pengadaan perbekalan farmasi akan menimbulkan biaya persediaan obat yang membesar sehingga dapat mengganggu kegiatan operasional pelayanan [3]. Penelitian ini bertujuan untuk membahas tugas pokok dan fungsi apoteker dalam pengelolaan obat, khususnya pada proses pengadaan perbekalan farmasi di rumah sakit.

\section{METODE PENELITIAN Metode}

Metode yang digunakan adalah metode analisis deskriptif, adalah suatu metode penelitian yang menggambarkan mengenai suatu keadaan secara obyektif. ${ }^{[4]}$ Pencarian sumber dilakukan dengan mengambil referensi (study literature) berupa jurnal ilmiah mengenai pelayanan kefarmasian di rumah sakit yang berkaitan dengan sumber data pengelolaan perbekalan farmasi pada tahap pengadaan perbekalan farmasi. Adapun kriteria yang digunakan antara lain, jurnal ilmiah merupakan naskah publikasi 10 tahun terakhir (tahun 2010-2020) yang membahas mengenai pengelolaan perbekalan farmasi khususnya pada tahap penyediaan perbekalan farmasi (obat dan alat kesehatan) di rumah sakit. 


\section{HASIL DAN PEMBAHASAN}

\section{A. Pengadaan Perbekalan Farmasi di Rumah Sakit.}

Pengadaan perbekalan di rumah sakit adalah salah satu kegiatan yang diupayakan dapat memenuhi perbekalan farmasi seperti obat atau alat kesehatan yang dibutuhkan oleh suatu rumah sakit sesuai dengan kebutuhan operasional yang telah ditetapkan oleh seorang apoteker di dalam proses perencanaan.[5] Pengadaan perbekalan farmasi di rumah sakit harus mampu menjamin ketersediaan obat/alat kesehatan, jumlah yang dibutuhkan, dan waktu yang tepat dengan harga yang terjangkau dan sesuai standar mutu yang telah ditetapkan oleh pihak rumah sakit.

Proses pengadaan perbekalan farmasi diawali dengan tahap pemilihan, menentukan jumlah kebutuhan, penyesuaian kebutuhan dengan dana yang tersedia, penentuan metode pengadaan, pemilihan pemasok perbekalan farmasi, penetapan spesifikasi kontrak, pemantauan proses pengadaan, serta metode pembayaran. Apoteker berperan penting dalam proses pengadaan, yaitu pemastian kualitas, mutu, dan persyaratan sediaan farmasi, alat kesehatan, serta bahan medis habis pakai. Terdapat beberapa hal yang harus diperhatikan dalam pengadaan perbekalan farmasi yaitu sebagai berikut [2].

1. Bahan baku obat disertai dengan sertifikat analisa.

2. Bahan berbahaya harus dilengkapi dengan data keamanan seperti Material Safety Data

Sheet.

3. Sediaan farmasi, alat kesehatan, dan bahan medis habis pakai harus memiliki Nomor Izin Edar.

4. Expired date untuk perbekalan farmasi minimal dua tahun, kecuali untuk perbekalan farmasi tertentu seperti vaksin dan reagensia [2].

Instalasi Farmasi Rumah Sakit merupakan bagian yang bertanggung jawab atas pengelolaan perbekalan farmasi di rumah sakit, mulai dari tahap seleksi, perencanaan, pengadaan, distribusi dan penggunaan obat. Dalam menjalankan tugas ini, bagian instalasi farmasi bekerja sama dengan bagian gudang dimana penerimaan obat dan penyimpanan obat dilakukan.

\section{B. Tahapan Pengadaan \\ Perbekalan Farmasi di RS.}

Ketersediaan perbekalan farmasi merupakan bagian yang sangat penting dalam melakukan pelayanan kesehatan. Oleh karena itu diperlukan suatu manajeman pengadaan yang baik dan bermutu. Hal pertama yang harus diperhatikan dalam proses pengadaan adalah perencanaan. Perencanaan dapat diartikan sebagai suatu proses penyusunan secara sistematik daftar perbekalan farmasi sehingga dapat mencapai tujuan yang telah ditetapkan. Perencanaan ini bertujuan untuk meningkatkan penggunaan secara efektif dan efisien dan menghindari kelebihan ataupun kekurangan perbekalan farmasi.

1. Pemilihan Item yang Akan Diadakan. 
Perencanaan diawali dengan tahap pemilihan yakni untuk menentukan apakah perbekalan tersebut diperlukan atau tidak. Pemilihan perbekalan farmasi yang didasarkan pada beberapa hal yakni standar standar dari masing-masing perbekalan farmasi; standar pedoman diagnosa dan terapi pola penyakit yang ada; keefektivan dan keamanan perbekalan farmasi; mutu; harga dan ketersediaan di pasaran [2].

2. Metode Pengadaan dalam Menentukan Jumlah Perbekalan. Perencanaan kemudian dilanjutkan dengan tahap penentuan jumlah yang akan dipesan. Penentuan jumlah dapat dilakukan dengan beberapa metode yakni metode konsumsi, ABC (Activity Based Costing), VEN dan morbiditas. Metode konsumsi merupakan metode penentuan berdasarkan analisa data konsumsi obat di tahun sebelumnya. Sebagai seorang Apoteker, hendaknya melakukan berbagai survei penggunaan perbekalan farmasi secara menyeluruh dan intensif pada tahun-tahun sebelumnya, agar di tahun berikutnya memperoleh ketersediaan perbekalan farmasi yang memadai. Hal-hal yang harus diperhatikan dalam metode konsumsi yakni stok awal dan sisa stok, daftar obat, penerimaan dan pengeluaran, kekosongan obat, obat kadaluarsa atau hilang, stok pengaman, pemakaian rata-rata pertahun, waktu tunggu, dan perkembangan pola kunjungan [6].

Metode ABC merupakan metode pengadaan berdasarkan tingkatan prioritas perbekalan farmasi berdasarkan urutan barang yang memerlukan anggaran terbanyak hingga terkecil. Sedangkan metode VEN berdasarkan tingkatan prioritas ketersediaan barang tersebut. Metode ini mengelompokkan barang ke dalam tiga jenis yakni vital (harus tersedia), esensial (perlu tersedia) atau non esensial (tidak prioritas untuk disediakan) [7].

Kelompok vital merupakan obat pokok seperti pelayanan kesehatan pokok, obat untuk penyakit penyebab kematian terbesar, kesehatan jiwa, dibutuhkan dengan cepat dan obat yang tidak dapat digantikan dengan obat lain. Kelompok esensial merupakan obat yang bersifat kausal yakni yang bekerja pada sumber penyebab penyakit dan tidak untuk mencegah kematian atau kecacatan secara langsung. Kelompok obat non esensial yakni digolongkan kedalam obat penunjang yakni untuk memberikan kenyamanan dan mengatasi keluhan ringan. Metode selanjutnya adalah morbiditas (epidemiologi) yakni berdasarkan pola perawatan standar, waktu tunggu pasien, jumlah kehadiran, dan kejadian penyakit yang umum terjadi [2].

3. Penyesuaian Antara Kebutuhan dan Dana

Pengadaan perbekalan farmasi juga harus memperhatikan keberadaan dana atau anggaran yang tersedia. Apoteker di bagian pengadaan harus membuat anggaran dengan mempertimbangkan sumber dana dan besaran dana yang ada dengan keperluan perbekalan. Sumber anggaran yang dapat diakses untuk memenuhi kebutuhan perbekalan 
farmasi adalah APBN, APBD, revolving fund, corporate social responsibility (CSR), donasi dan asuransi. Data yang diperlukan dalam melakukan penganggaran adalah sisa stok, biaya obat dan penggunaan per tahunnya, serta kompilasi biaya perbekalan farmasi [7].

4. Pemilihan Metode Pengadaan.

Pegadaan umumnya dilakukan dengan beberapa cara yaitu pembelian dari distributor, produksi sendiri sediaan farmasi, dan sumbangan/dropping/ hibah. Metode pengadaan yang dipilih harus disesuaikan dengan jenis kebutuhan dari Rumah Sakit tersebut, sehingga tidak menutup kemungkinan dalam satu Rumah Sakit menggunakan semua metode pengadaan tersebut.

\subsection{Pembelian}

Pembelian merupakan salah satu dari serangkaian proses pengadaan perbekalan farmasi yang berkaitan langsung dengan Pedagang Besar Farmasi (PBF). Pembelian perbekalan farmasi harus dapat direncanakan dengan baik dan perlu memperhitungkan beberapa faktor penting yaitu mencari dan memilih PBF yang manajemennya baik, mampu menjamin mutu produk dan menawarkan harga terjangkau, serta mampu menyediakan produk dengan lead time yang cepat. Proses pembelian merupakan siklus yang berjalan terus-menerus dan memiliki tahapan yang baku. Secara garis besar proses pembelian dimulai dari perencanaan perbekalan farmasi yang akan diadakan hingga proses penyimpanan barang setelah diterima dari pemasok. Beberapa hal yang harus diperhatikan selama proses pembelian yakni, kriteria umum dan kriteria mutu perbekalan farmasi, persyaratan yang harus dipenuhi pemasok, penentuan waktu hingga kedatangan produk, dan monitoring rencana pengadaan sesuai jenis, jumlah, dan waktu..$^{[7,8]}$ Pada proses pembelian itu sendiri terdapat lima metode yang umum digunakan yaitu tender terbatas, tender terbuka, pembelian dengan sistem tawar menawar, pembelian langsung, dan $E$ catalogue.

a. Tender terbuka merupakan metode pengadaan yang dapat dilakukan oleh seluruh rekanan yang telah terdaftar, dan telah memenuhi kriteria yang ditetapkan. Metode ini dianggap lebih menguntungkan pada saat penentuan harga. Dalam pelaksanaannya diperlukan perhatian penuh, serta waktu yang cukup lama sehingga diperlukan staf yang kuat [7].

b. Tender terbatas, dikenal pula dengan sebutan lelang tertutup. Metode ini hanya berlaku untuk beberapa rekanan tertentu yang telah terdaftar dan telah memenuhi kriteria. Harga yang ditentukan masih terkendali. Apabila dibandingkan dengan metode lelang terbuka, pada metode ini beban kerja dan tenaga yang dibutuhkan lebih ringan [7].

c. Pembelian dengan sistem tawarmenawar dipilih apabila item yang akan diadakan tidak begitu penting, jumlah item yang diperlukan tidak banyak, serta 
umumnya untuk pengadaan item tertentu diperlukan pendekatan langsung [7].

d. Pembelian langsung dari distributor dilakukan apabila item diperlukan dalam jumlah yang sedikit, dan ketersediaanya diperlukan segera. Kelemahan utama metode ini adalah harga item yang relatif lebih mahal [7].

e. E-Catalogue merupakan sistem informasi yang berbasis elektronik yang memuat jenis, spesifikasi, serta harga produk dari penyedia produk. Program ini dirancang dengan tujuan untuk peningkatan transparansi, efektifitas, dan efisiensi pada pelaksanaan pengadaan obat sehingga hasilnya dapat dipertanggungjawabkan.

Pembayaran produk dapat dilakukan melalui metode $E$ Purchasing [8].

4.2 Produksi Perbekalan Farmasi

Produksi sendiri perbekalan farmasi merupakan kegiatan untuk menghasilkan produk baru dengan kriteria tertentu yang hanya dapat dilakukan di Rumah Sakit tersebut dan ditujukan guna memenuhi kebutuhan pelayanan. Kegiatan ini meliputi proses membuat ataupun mengubah bentuk, serta mengemas ulang sediaan. Adapun jenis sediaan yang diperbolehkan untuk diproduksi sendiri oleh instalasi farmasi yaitu sediaan farmasi yang tidak dijual dipasaran, sediaan formula khusus, sediaan dengan harga lebih murah apabila diproduksi sendiri, sediaan yang perlu pengemasan kembali (repacking), sediaan nutrisi parenteral, sediaan untuk kepentingan penelitian, sediaan yang harus dibuat baru, dan rekonstitusi sediaan sitostatika. Seluruh sediaan yang diproduksi sendiri tentunya harus memiliki mutu yang terjamin dan hanya dapat digunakan di Rumah Sakit tersebut [7,8].

4.3 Sumbangan/Dropping/Hibah

Perbekalan farmasi yang berasal dari sumbangan/hibah, pada prinsipnya sesuai dengan aturan umum dari pengelolaan perbekalan farmasi. Kegiatan penerimaan dan penggunaan perbekalan farmasi pada metode pengadaan ini harus dibuatkan pencatatan dan pelaporan yang lengkap oleh Instalasi Farmasi. Seluruh kegiatan tahapan dari awal proses penerimaan harus disertai dengan dokumen administrasi yang dibuat dengan jelas dan lengkap. Penyedia perbekalan farmasi dapat menyediakan perbekalan farmasi yang disesuaikan dengan kebutuhan pasien di Rumah Sakit tersebut. Pimpinan Rumah Sakit atas rekomendasi Instalasi Farmasi dapat mengembalikan atau menolak sumbangan/dropping/hibah, jika perbekalan farmasi yang diberikan tidak dibutuhkan Rumah Sakit [7,8].

5. Pemilihan Pemasok

Pemasok merupakan suatu organisasi ataupun lembaga yang bertugas sebagai penyedia produk yang dibutuhkan konsumen. Pemasok perbekalan farmasi Rumah Sakit umumnya PBF (Pedagang Besar Farmasi) atau dapat pula berasal dari Industri Farmasi. Pemilihan pemasok sesuai dengan kriteria yang ditetapkan perlu dilakukan untuk dapat 
memperoleh perbekalan farmasi yang memenuhi spesifikasi dan persyaratan mutu. Jadi, pemilihan pemasok yang memenuhi syarat merupakan komponen penting dari Praktik Pengadaaan Obat Yang Baik (PPOB) [9].

Proses seleksi yang dapat dilakukan pihak Rumah Sakit terhadap calon pemasok yakni membuat persyaratan yang harus dipenuhi oleh calon pemasok, kemudian melakukan penawaran, dan memilih pemasok yang paling mendekati persyaratan. IFRS perlu menetapkan kriteria pemasok yang sesuai. Berikut kriteria yang dapat dipertimbangkan untuk digunakan dalam memilih pemasok perbekalan farmasi [9].

1) Pemasok telah terdaftar secara hukum untuk dapat menjalankan fungsinya.

2) Pemasok memiliki akreditasi yang sesuai CPOB dan ISO 9000 .

3) Pemasok memiliki reputasi baik, dalam arti tidak pernah:

a. Melakukan pelanggaran hukum.

b. Memproduksi dan/atau memdistribusikan produk yang mutunya tidak memenuhi persyaratan.

c. Menyediakan produk yang dilarang untuk beredar.

4) Memiliki tanggung jawab sebagai pemasok yang mampu menyediakan produk dengan jaminan mutu dan harga yang terjangkau [9].

Berikut adalah identifikasi pemasok yang dapat dilakukan IFRS untuk memastikan kualifikasi dari pemasok yang akan dipilih. Hal-hal lain mungkin dibutuhkan untuk mengoptimalkan identifikasi pemasok [9]

1) Melakukan evaluasi terhadap sistem mutu yang diterapkan oleh pemasok.

2) Melakukan analisis informasi mengenai kinerja pemasok.

3) Pada pemasok baru, penting dilakukan pemeriksaan kondisi produk secara visual, pemeriksaan penandaan, serta kemasan.

4) Mengkaji mutu produk, harga produk, dan respon pemasok apabila terdapat masalah.

5) Mengevaluasi pengalaman yang relevan dengan pemasok.

6) Kemampuan pemasok dalam memberikan layanan serta dukungan.

7) Kemampuan dibidang logistik termasuk didalamnya lokasi dan sumber.

6. Penentuan Kesepakatan

Adapun hal-hal yang perlu disepakati oleh dua pihak yakni antara IFRS dan pemasok adalah sebagai berikut [9].

1) Kesepakatan Tentang Jaminan Mutu Pasokan

2) Dalam hal kesepakatan mutu, pihak IFRS dan pemasok perlu membuat kesepakatan yang tegas dan jelas mengenai penjaminan mutu produk yang dipasok.

3) Kesepakatan Mengenai Metode Verifikasi 
4) Kesepakatan ini mencakup kesepakatan terkait metode verifikasi yang digunakan untuk memastikan kesesuaian mutu produk dengan persyaratan mutu yang telah ditetapkan. Kesepakatan didalamnya mencakup pertukaran data pengujian dan/atau data inspeksi yang dibutuhkan untuk peningkatan mutu selanjutnya.

5) Kesepakatan untuk Penyelesaian Perselisihan

6) Kesepakatan ini mencakup penyelesaian perselisihan yang mungkin terjadi di kemudian hari antara pihak IFRS dengan pemasok terkait dengan mutu produk dari pemasok dikemudian hari.

7. Evaluasi Proses Pengadaan

Proses pengadaan perbekalan farmasi rumah sakit memiliki pengaruh yang besar terhadap dana dan ketersediaan rumah sakit. Sehingga perlu dilakukan evaluasi terhadap proses pengadaan untuk mengetahui sejauh mana efektivitas proses pengadaan yang dilakukan. Dengan melakukan evaluasi, apoteker dapat mengetahui hal apa yang harus dioptimalkan dalam pengadaan perbekalan farmasi selanjutnya. Evaluasi yang dapat dilakukan pada tahap pengadaan antara lain, persentase kesesuaian antara perencanaan obat dengan masingmasing obat, persentase modal dana yang tersedia dengan keseluruhan dana yang dibutuhkan, frekuensi pengadaan tiap item obat pertahun, indikator persentase alokasi dana pengadaan obat yang tersedia, frekuensi kurang lengkapnya surat pesanan atau faktur, serta frekuensi tertundanya pembayaran oleh rumah sakit terhadap waktu yang disepakati [10].

\section{Hal-Hal yang Diperhatikan dalam Pengadaan Perbekalan Farmasi}

Terdapat tiga elemen penting yang perlu diperhatikan dalam proses pengadaan, yaitu pemilihan pengadaan yang dipilih, penyusunan dan persyaratan kontrak kerja, serta pemesanan barang agar sesuai macam, waktu, dan tempat. Selain itu, rentang kedaluarsa obat juga perlu diperhatikan yaitu minimal dua tahun. Obat dengan waktu kedaluarsa yang singkat perlu dihindari pengadaannya dalam jumlah yang besar. Pelaksanaan tata kelola perbekalan yang baik dapat tercapai dengan memperhatikan beberapa hal, seperti: mekanisme penyanggahan bagi peserta tender; kriteria untuk menjadi anggota panitia pengadaan, pernyataan tidak adanya konflik kepentingan bagi anggota panitia pengadaan; prosedur yang transparan; SOP pengadaan; prosedur tetap untuk pemeriksaan pengiriman; pembatasan masa kerja anggota panitia pengadaan; standar kompetensi bagi anggota tim pengadaan; sistem monitoring post tender dan pelaporan kinerja pemasok; sistem manajemen informasi untuk pelaporan perbekalan farmasi yang bermasalah; serta audit secara rutin pada proses pengadaan [7]. 


\section{KESIMPULAN}

Berdasarkan studi literatur yang telah dilakukan pada penelitian ini, adapun kesimpulan yang diperoleh yaitu tugas dan fungsi apoteker di bidang pengelolaan perbekalan farmasi di rumah sakit khususnya pada tahap pengadaan diantaranya memilih metode untuk menentukan jumlah perbekalan farmasi agar disesuaikan dengan kebutuhan dan dana yang tersedia, menentukan metode pengadaan (pembelian), memilih pemasok dan melakukan evaluasi proses pengadaan sediaan farmasi di rumah sakit.

\section{UCAPAN TERIMA KASIH}

Terima kasih kepada anggota tim penelitian serta dosen pembimbing yang memberikan dukungan selama penelitian hingga penulisan artikel.

\section{DAFTAR PUSTAKA}

[1] Bachtiar, M. A. P., A. Germas., N. Andarusito. 2019. Analisis Pengelolaan Obat Di Instalasi Rawat Inap Rumah Sakit Jantung Bina Waluya Jakarta Timur Tahun 2019. Jurnal Manajemen dan Administrasi Rumah Sakit Indonesia. Vol 3(2): 119-130.

[2] Rusli. 2016. Farmasi Rumah Sakit dan Klinik. Jakarta: Kementerian Kesehatan Republik Indonesia.

[3] Febreani, S.H. dan D. Chalidyanto. 2016. Pengelolaan Sediaan Obat Pada Logistik Farmasi Rumah Sakit Umum Tipe B di Jawa Timur. Jurnal
Administrasi Kesehatan

Indonesia Vol.4(2): 136-145.

[4] Dadiani, N.M., W. A. Lolo., I. Antasionasti. 2020. Persepsi Perawat Terhadap Peran Apoketer Dalam Pelayanan Kefarmasian Di Rumah Sakit Robert Wolter Mongisidi Manado. Pharmacon. 9(2): 310317.

[5] Permenkes RI. 2016. Peraturan Menteri Kesehatan Nomor 72 tahun 2016 tentang Standar Pelayanan Kefarmasian $d i$ Rumah Sakit. Jakarta: Menteri Kesehatan Republik Indonesia.

[6] Walujo, D.S., P.E. Yudha, F.A. Septria. 2018. Analisis Perencanaan Obat dengan Menggunakan Metode Konsumsi di Instalasi Farmasi Dinas Kesehatan Kota Kediri Tahun 2017. Jurnal Wiyata 5(10):24-28.

[7] Direktorat Jenderal Bina Kefarmasian. 2010. Pedoman Pengelolaan Perbekalan Farmasi di Rumah Sakit. Jakarta: Kementerian Kesehatan Republik Indonesia.

[8] Kemenkes RI. 2014. Peraturan Menteri Kesehatan Republik Indonesia Nomor 63 Tahun 2014 Tentang Pengadaan Obat Berdasarkan Katalog Elektronik (E-Catalogue). Jakarta: Menteri Kesehatan Republik Indonesia.

[9] Siregar, C.J.P. 2004. Farmasi Rumah Sakit: Teori dan Penerapan. Jakarta: Penerbit Buku Kedokteran EGC.

[10] Oktaviani, N., G. Pamudji, dan Y. Kristanto. 2018. Evaluasi 
Pengelolaan Obat Di Instalasi Farmasi Rumah Sakit Umum Daerah Provinsi NTB Tahun 2017. Jurnal Farmasi Indonesia Vol.15(2): 135-147. 